Original Research Paper

\title{
Organoleptic Value and Number of Bacteria Sausage Rabbit Meat Based On Levels Green Bean Flour Substitution
}

\author{
D.W. Sari ${ }^{1}$, Bulkaini ${ }^{1 *}$, Djoko Kisworo ${ }^{1}$ \\ ${ }^{1}$ Faculty of Animal Husbandry, University of Mataram Jalan Majapahit No.62 Mataram West Nusa \\ Tenggara.
}

\author{
Article History \\ Received : May $10^{\text {th }}, 2021$ \\ Revised : May $28^{\text {th }}, 2021$ \\ Accepted : June $20^{\text {th }}, 2021$ \\ Published : June $28^{\text {th }}, 2021$ \\ *Corresponding Author: \\ Bulkaini, \\ Faculty of Animal Husbandry, \\ University of Mataram Jalan \\ Majapahit No.62 Mataram \\ West Nusa Tenggara. \\ Email: b_kaini@yahoo.com
}

\begin{abstract}
Sausage is a food ingredient that comes from pieces of meat that are ground and seasoned, and put into a casing so that it is oval in shape. One type of meat that can be processed into sausage is rabbit meat. This study aims to determine the effect of the level of substitution of mung bean flour on the organoleptic value and the number of bacteria in rabbit meat sausage. The research materials used were $3000 \mathrm{~g}$ rabbit meat, mung bean flour, skim milk, and a severala of spices. The experimental design used was a completely randomized design (CRD) with 4 treatments, namely the addition of $0 \%, 15 \%$, $30 \%$ and $45 \%$ mung bean flour, with 4 replications. The results showed that the level of substitution of mung bean flour had a significant effect $(\mathrm{P}<0.05)$ on the color, taste and texture of rabbit meat sausage and had no significant effect $(\mathrm{P}>0.05)$ on the aroma and number of bacteria. The addition of $15 \%$ mung bean flour gave the best organoleptic values, namely: Color 5.28 (light), aroma 5.31 (good), taste 5.95 (tasty), texture 5.99 (soft) with a bacterial count of $2.00 \times 103$ $\mathrm{cfu} / \mathrm{g}$, which is below the standard for bacterial contamination of sausages set by SNI 1995, which is $1 \times 103 \mathrm{cfu} / \mathrm{g}$.
\end{abstract}

Keywords: Organoleptic value, sausage, bacteria test

\section{Pendahuluan}

Sosis merupakan salah satu hasil diversifikasi produk pangan asal hewan yang merupakan campuran dari daging halus dengan tepung, bumbu-bumbu serta bahan tambahan makanan lain yang diizinkan dimasukan ke dalam selongsong sosis (BSN, 1995). Dalam proses pembuatan sosis, bahan baku sosis terdiri dari dua yaitu bahan utama dan bahan tambahan. Bahan utama untuk proses pembuatan sosis terdiri atas daging, es, minyak, garam dan lemak. Sedangkan bahan tambahannya dapat berupa: bumbu-bumbu, bahan pengikat, bahan pengisi, bahan penyedap, dan bahan tambahan lainya yang diizinkan (Irianti, 2019).

Salah satu daging yang dapat digunakan dalam pembuatan sosis adalah daging kelinci karena daging kelinci memiliki protein sebesar 20,85, kadar lemak 10,2\% dan kandungan kalori sebesar 7,3\% dengan tekstur daging yang halus (Rukmana, 2014). Dalam pembuatan sosisi diperlukan bahan pengisi (filler) seperti tepung tapioka, tepung jagung, tepung kacang hijau atau tepung beras (Irianti, 2019). Selanjutnya dikatakan bahwa salah satu fungsi dari bahan pengisi adalah meningkatkan stabilitas emulsi, meningkatkan daya ikat produk daging, meningkatkan flavor, mengurangi pengerutan selama pemasakan, dan mengurangi biaya (Bulkaini et al., 2019).

Lestari et al. (2017) menyatakan bahwa dalam $100 \mathrm{~g}$ Tepung kacang hijau mempunyai kandungan gizi seperti: protein 21,46 g, lemak 1,64 g, karbohidrat 63,55 g, air 11,42 g, abu 2,36 $\mathrm{g}$, dan serat $2,46 \%$. Selanjutnya Bulkaini et al.(2014) menyatakan bahwa sifat fisik sosis daging sapi dengan penambahan tepung kacang hijau sangat bervariasi, baik $\mathrm{pH}$ maupun susut masak. Nilai $\mathrm{pH}$ sosis daging sapi bedasarkan perlakuan persentase tambahan tepung kacang hijau berkisar antara 4,8-5,5\% sedangkan susut masak berkisar antara 3,14-8,11\%. Hasil penelitian Prasetyo et al.(2015) melaporkan bahwa sosis daging ayam dengan penambahan bahan 10-30\% tepung tapioka mempunyai nilai pH 3,83-6,03\%, susut masak 13,33-16,67\%, DIA $39,41-50,33 \%$, dan keempukan 2,00-3,33 $\mathrm{kg} / \mathrm{cm}^{2}$.

Bakteri yang terdapat pada sosis pada umurnya relatif lebih rendah dibandingkan dengan bakteri yang terdapat dalam daging sebelum diolah. (Soeparno, 2009) menyatakan 
bahwa ada dua faktor yang berpengaruh terhadap pertumbuhan bakteri pada daging yaitu faktor intrinsik seperti nutrisi daging, kadar air, dan $\mathrm{pH}$ daging sedangkan faktor ekstrinsik seperti temperatur, kelembapan relatif, bentuk olahan daging (sosis). Selanjutnya dikatakan bahwa kandungan jumlah bakteri yang terdapat pada olahan daging (sosis) bisa meningkat jika pengolahan sosis tidak ditangani secara higienis. Berdasarkan hasil penelitian sebelumnya, maka dilakulan penelitian dengan judul: nilai organoleptik dan jumlah bakteri sosis daging kelinci berdasarkan level substitusi tepung kacang hijau.

\section{Bahan dan Metode}

\section{Materi penelitian}

Materi yang digunakan dalam penelitian ini adalah daging kelinci sebanyak $3000 \mathrm{~g}$ yang diperoleh dari hasil penyembelihan 3 ekor kelinci jantan peranakan New Zealand White.

\section{Formula pembuatan sosis}

Formula pembuatan sosis dengan substitusi tepung kacang hijau disajikan pada Tabel 1.

Tabel 1. Bahan dan Komposisi Adonan Sosis Daging Kelinci

\begin{tabular}{lccccccccc}
\hline \multirow{2}{*}{ Bahan } & \multicolumn{3}{c}{ Adonan I } & \multicolumn{2}{c}{ Adonan II } & \multicolumn{2}{c}{ Adonan III } & \multicolumn{2}{c}{ Adonan IV } \\
\cline { 2 - 9 } & gram & $\%$ & gram & $\%$ & gram & $\%$ & gram & $\%$ \\
\hline Daging & 700 & 55 & 550 & 55 & 400 & 40 & 250 & 25 \\
Kacang Hijau & 0 & 0 & 150 & 15 & 300 & 30 & 450 & 45 \\
Tepung Tapioka & 70 & 7 & 70 & 7 & 70 & 7 & 70 & 7 \\
Susu skim & 60 & 6 & 60 & 6 & 60 & 6 & 60 & 6 \\
Minyak & 40 & 4 & 40 & 4 & 40 & 4 & 40 & 4 \\
Garam & 10 & 1 & 10 & 1 & 10 & 1 & 10 & 1 \\
Bawang putih & 10 & 1 & 10 & 1 & 10 & 1 & 10 & 1 \\
Merica & 10 & 1 & 10 & 1 & 10 & 1 & 10 & 1 \\
STTP & 20 & 2 & 20 & 2 & 20 & 2 & 20 & 2 \\
Pala & 10 & 1 & 10 & 1 & 10 & 1 & 10 & 1 \\
Es batu & 60 & 6 & 60 & 6 & 60 & 6 & 60 & 6 \\
Penyedap & 10 & 1 & 10 & 1 & 10 & 1 & 10 & 1 \\
\hline \multicolumn{1}{c}{ Total } & Total & $\mathbf{1 0 0 0}$ & $\mathbf{1 0 0}$ & $\mathbf{1 0 0}$ & $\mathbf{1 0 0}$ & $\mathbf{1 0 0 0}$ & $\mathbf{1 0 0}$ & $\mathbf{1 0 0 0}$ \\
\end{tabular}

Keterangan: STTP = Sodium TripolyPhosphate

\section{Pembuatan sosis daging kelinci}

Pembuatan sosis daging kelinci dengan penambahan tepung kacang hijau dapat dijelaskan sebagai beriut: 1) Membersihkan daging dari lemak dan tulang; 2) Daging kelinci sebanyak $3000 \mathrm{~g}$ digiling dengan mesin giling daging sambil menambahkan es batu di dalamnya; 3) Membuat adonan sosis yang terdiri dari daging giling, tepung kacang hijau, tepung tapioka, susu skim, bawang putih, Sodium TripolyPhosphate (STTP), garam, merica, pala, minyak goreng, dan penyedap rasa; 4) Adonan yang sudah halus dan bercampur rata dimasukkan dalam selongsong sosis dan 5) Perebusan sosis. Diagram alir pembuatan sosis disajikan pada Gambar 1. 


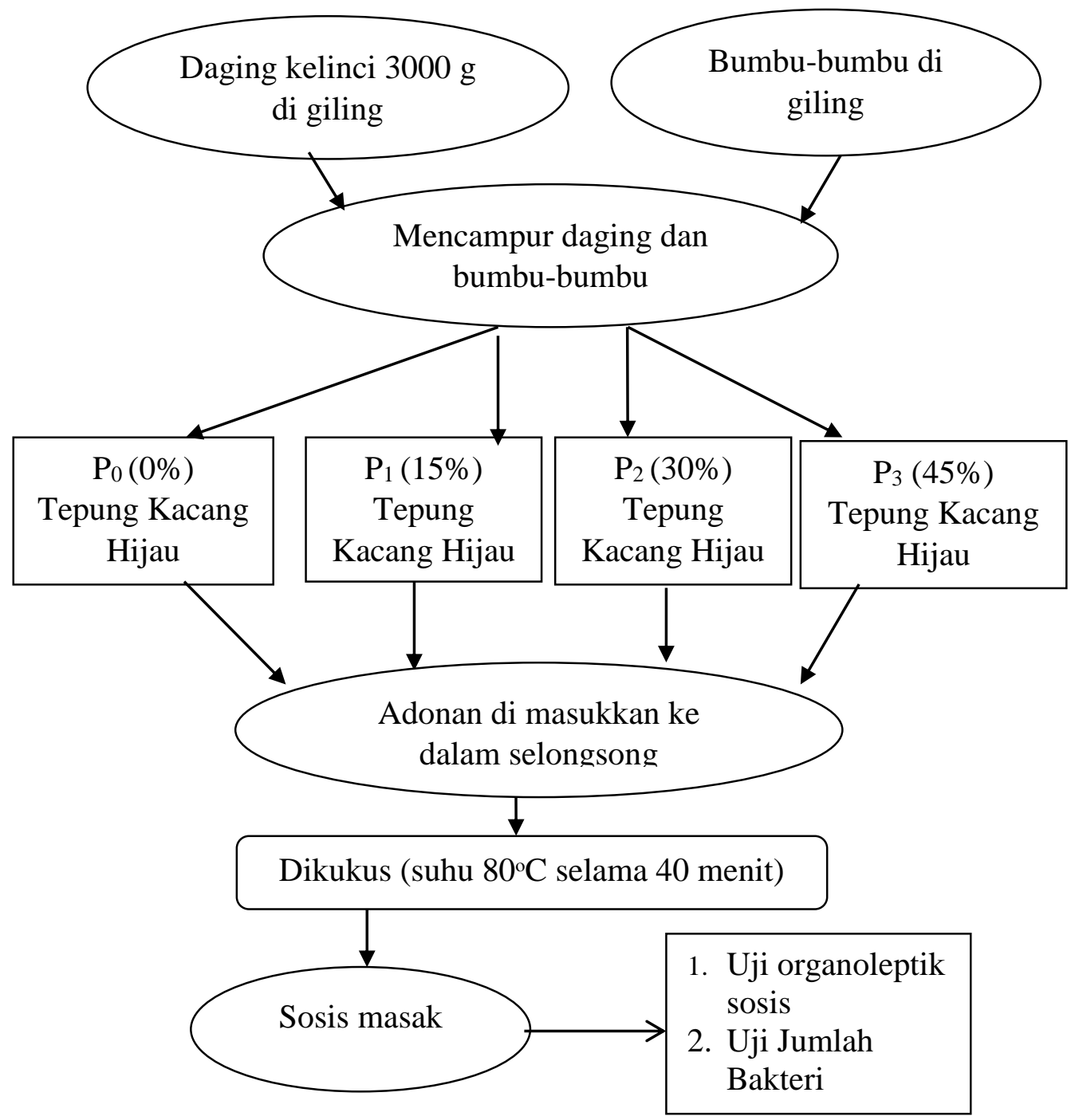

Gambar 1. Diagram Alir Pembuatan Sosis Daging Kelinci.

\section{Uji Organoleptik dan kandungan bakteri}

Penilaian organoleptik sosis daging kelinci yang meliputi aroma, rasa, warna, dan tekstur dilakukan dengan metode uji sensori menggunakan 15 penelis tidak terlatih dengan kriteria skor pengujian hedonik 1-10 (Setyaningsih et al, 2010; Soekarto, 1981), sedangkan pengamatan terhadap kandungan bakteri sosis daging kelinci dilakukan dengan metode Total Plate Count (Barus et al., 2017).

\section{Analisis Data}

Data hasil penelitian berupa nilai organoleptik dan jumlah bakteri sosis daging kelinci dianalisis mengggunakan Analisis One way anova dan dilanjutkan dengan uji Duncan't Multiple Range test untuk melihat perbedaan diantara perlakuan, program SPSS versi 16 (Stell dan Torrie, 2015).

\section{Hasil dan Pembahasan}

\section{Nilai uji organoleptik sosis daging kelinci}

Rata-rata nilai uji organoleptik sosis daging kelinci dengan substitusi tepung kacang hijau pada level yang berbeda disajikan pada Tabel 2. 
Tabel 2. Nilai Uji Organoleptik Sosis Daging Kelinci dengan Substitusi Tepung Kacang Hijau.

\begin{tabular}{llllll}
\hline \multirow{2}{*}{ Sifat Organoleptik } & \multicolumn{4}{c}{ Perlakuan Substitusi Tepung Kacang Hijau } & \multirow{2}{*}{ Ket. } \\
\cline { 2 - 5 } & \multicolumn{1}{c}{$\mathrm{P} 0(0 \%)$} & $\mathrm{P} 1(15 \%)$ & $\mathrm{P} 2(30 \%)$ & $\mathrm{P} 3(45 \%)$ & \\
\hline Warna & $4,86 \pm 0,14^{\mathrm{ab}}$ & $5,28 \pm 1,00^{\mathrm{c}}$ & $4,74 \pm 0,88^{\mathrm{a}}$ & $4,92 \pm 1,10^{\mathrm{bc}}$ & $\mathrm{S}$ \\
Aroma & $5,71 \pm 0,22$ & $5,31 \pm 0,68$ & $5,19 \pm 0,21$ & $5,00 \pm 0,44$ & $\mathrm{NS}$ \\
Rasa & $5,70 \pm 0,58^{\mathrm{bc}}$ & $5,95 \pm 1,49^{\mathrm{c}}$ & $5,65 \pm 0,82^{\mathrm{ab}}$ & $4,93 \pm 0,79^{\mathrm{a}}$ & $\mathrm{S}$ \\
Tekstur & $5,85 \pm 0,28^{\mathrm{bc}}$ & $5,99 \pm 1,17^{\mathrm{c}}$ & $5,66 \pm 0,99^{\mathrm{ab}}$ & $4,96 \pm 0,66^{\mathrm{a}}$ & $\mathrm{S}$ \\
\hline
\end{tabular}

Keterangan: Superskrip yang berbeda pada baris yang sama menunjukan perbedaan yang nyata $(\mathrm{P}<0,05) ; \mathrm{NS}=$ Non Signifikan; $\mathrm{S}=$ Signifikan.

\section{Warna}

Hasil analisis One way anova menunjukkan bahwa level substitusi tepung kacang hijau pada pembuatan sosis daging kelinci bepengaruh nyata $(\mathrm{P}<0,05)$ terhadap warna. Hasil penelitian menunjukkan nilai uji warna sosis berturut-turut : $\mathrm{P} 0$ dengan skor 4,86 (gelap), P1 dengan skor 5,28 (terang), P2 dengan skor 4,74 (gelap) dan P3 dengan skor 4,92 (gelap). Nilai rata-rata uji warna menunjukkan bahwa pada P1 lebih tinggi dibandingkan P0, P2 dan P3.

Hasil uji Duncan menunjukkan bahwa nilai uji warna sosis pada P1 berbeda nyata $(\mathrm{P}<0,05)$ dengan $\mathrm{P} 0$ dan $\mathrm{P} 2$, sedangkan $\mathrm{P} 1$ dengan P3 tidak berbeda nyata $(\mathrm{P}>0,05)$. Substitusi tepung kacang hijau pada sosis daging kelinci memberikan efek warna yang disukai panelis terdapat pada level tepung $15 \%$ sedangkan pada level tepung 30\% dan $45 \%$ akan memberikan warna yang semakin gelap karena kadar warna pada tepung yang tinggi akan membuat perubahan pada warna pada daging yang disebabkan oleh kandungan klorofil yang terkandung pada kulit biji kacang hijau. Hal ini sesuai dengan pendapat Yunisuryani (2013), bahwa kulit kacang hijau mengandung pigmen klorofil yaitu pigmen penyebab warna hijau.

\section{Aroma}

Hasil analisis One way anova menunjukkan bahwa level substitusi tepung kacang hijau pada pembuatan sosis daging kelinci tidak berpengaruh nyata $(\mathrm{P}>0,05)$ terhadap aroma sosis. Hasil penelitian menunjukkan nilai uji aroma sosis berturut-turut : P0 dengan skor 5,71 (sedap), P1 dengan skor 5,31 (sedap), P2 dengan skor 5,19 (sedap) dan P3 dengan skor skor 5,00 (sedap). Aroma adalah salah satu faktor yang menentukan mutu dari bahan pangan dan pada umumnya aroma yang diterima oleh panelis lebih dipengaruhi oleh berbagai ramuan atau campuran bahan pembuatan sosis (Winarno, 2004). Soeparno (2005), menyatakan bahwa bau atau aroma dan rasa banyak ditentukan oleh precursor yang larut dalam lemak, dan pembebasan substansi atsiri (volatil) yang terdapat dalam daging. Hasil penelitian ini tidak jauh berbeda dengan hasil penelitian Purwosari dan Afifah (2016), menunjukkan bahwa penggunaan jenis bahan pengisi tidak berpengaruh nyata $(\mathrm{P}>0,05)$ terhadap aroma sosis dan penggunaan jumlah bahan pengisi juga tidak berpengaruh nyata $(\mathrm{P}>0.05)$.

\section{Rasa}

Hasil analisis One way anova menunjukkan bahwa level substitusi tepung kacang hijau pada pembuatan sosis berpengaruh nyata $(\mathrm{P}<0,05)$ terhadap rasa sosis daging kelinci. Rata-rata nilai rasa sosis yang diperoleh berturutturur: P0 memiliki skor 5,70 (enak), P2 memiliki skor 5,95 (enak), P3 memiliki skor 5,65 (enak) dan P4 mempunyai skor sebesar 4,93 (tidak enak). Hasil penelitian ini menunjukkan bahwa tingkat kesukaan panelis terhadap rasa sosis daging kelinci berdasarkan skor penerimaan terdapat pada level tepung kacang hijau 15\% dimana dengan penambahan tepung kacang hijau $15 \%$ akan memberikan cita rasa yang enak dibandingkan dengan perlakuan yang lain. Soeparno (2005) menjelaskan bahwa rasa produk olahan daging (sosis) banyak ditentukan oleh precursor yang larut dalam air dan lemak, dan pembebasan substansi atsiri (volatil) yang terdapat di dalam daging. Dijelaskan juga bahwa rasa merupakan atribut sensori yang penting dalam penentuan keputusan konsumen untuk menerima atau menolak suatu produk makanan. 
Produk yang memiliki warna, aroma, dan tekstur yang baik, tetapi jika rasanya tidak enak maka produk tersebut akan ditolak (Kusumastuti dan Fitriyono, 2013).

Produk olahan yang memiliki rasa kacang hijau terlalu kuat menyebabkan panelis tidak menyukainya. Hal serupa juga dilaporkan oleh Genisa et al., (2015) yang menyatakan bahwa pada pembuatan bakso berbahan dasar tepung kacang merah dan terigu akan meghasilkan nilai kesukaan yang redah. Purwosari dan Afifah (2016) menyatakan bahwa penambahan level tepung $15 \%$ tidak akan menghilangkan cita rasa khas dari daging itu sendiri dan rasa yang timbul pada sosis selain berasal dari daging juga berasal dari bumbu.bumbu yang ditambahkan di dalamnya.

\section{Tekstur}

Hasil analisis One way anova menunjukkan bahwa level substitusi tepung kacang hijau pada pembuatan sosis berpengaruh nyata $(\mathrm{P}<0,05)$ terhadap tekstur sosis daging kelinci. Secara rata-rata skor tekstur sosis daging kelinci berdasarkan level substitusi tepung kacang hijau berturut-turut: P0 sebesar 5,85 (lembut), P1 sebesar 5,99 (lembut), P2 sebesar 5,66 (lembut) dan pada P3 mempunyai nilai skor sebesar 4,96 (sedikit keras). Hasil penelitian menunjukkan bahwa penambahan tepung kacang hijau pada level tepung $15 \%$ memberikan nilai rata-rata tekstur yang lebih tinggi dibandingkan dengan dengan level substitusi 30\%, 45\% dan tanpa penambahan tepung kacang hijau, tetapi masih tergolong lembut. Hal ini mungkin disebabkan karena semua bahan yang digunakan dalam pembuatan sosis dilakukan proses penggilingan bahan sehingga diperoleh adonan bahan yang relatif sama dari segi tingkat kelembutannya. Pada substitusi tepung kacang hijau $45 \%$ menyebabkan sosis terksturnya agak keras, hal ini disebabkan karena masih adanya kandungan partikel kasar pada tepung kacang hijau.

Hasil penelitian ini sejalan dengan pendapat Winarno (2004) bahwa perubahan tekstur atau viskositas bahan dapat mengubah rasa dan bau yang timbul karena dapat mempengaruhi kecepatan timbulnya rangsangan terhadap sel reseptor olfaktori dan kelenjar air liur. Diperjelas lagi oleh Meilgaard et al. (2000), bahwa nilai tekstur sangat dipengaruhi oleh kepekaan tekstur rabaan oleh tangan panelis, keempukan, kemudahan dikunyah dan kerenyahan makanan.

\section{Jumlah Bakteri Sosis Daging Kelinci}

Hasil pengujian jumlah bakteri yang terdapat pada sosis daging kelinci dengan substitusi tepung kacang hijau pada level yang berbeda disajikan dalam Tabel 2 .

Tabel 2. Hasil Uji Jumlah Bakteri Sosis Daging Kelinci Dengan Penambahan Level Tepung Kacang Hijau (log cfu/g)

\begin{tabular}{llllll}
\hline \multirow{2}{*}{ Uji Bakteri } & \multicolumn{4}{c}{ Perlakuan Substitusi Tepung Kacang Hijau } & \multirow{2}{*}{ Ket. } \\
\cline { 2 - 5 } & P0 (kontrol) & P1 (15\%) & P2 (30\%) & P3 (45\%) & \\
\hline $\begin{array}{l}\text { Jumlah bakteri (log } \\
\text { cfu/g) }\end{array}$ & $2,07 \pm 0,15$ & $2,00 \pm 0,00$ & $2,07 \pm 0,15$ & $1,75 \pm 0,5$ & NS \\
\hline
\end{tabular}

Keterangan: NS = Non Signifikan

Hasil analisis One way anova menunjukkan bahwa level substitusi tepung kacang hijau pada pembuatan sosis daging kelinci berpengaruh sangat nyata $(\mathrm{P}<0,01)$ terhadap jumlah bakteri yang terdapat pada sosis dalam satuan $\log \mathrm{cfu} / \mathrm{g}$. Hasil penelitian ini membuktikan bahwa rata-rata jumlah bakteri yang terdapat pada sosis berdasarkan level substitusi tepung kacang hijau berturut-turut: $\mathrm{P} 0=$ sebesar 2,07 log cfu/g, P1= 2,00 log cfu/g, $\mathrm{P} 2=2,07 \log \mathrm{cfu} / \mathrm{g}$ dan P3 sebesar 1,75 log cfu/g. Hasil penelitian ini memberikan gambaran bahwa penambahan tepung kacang hijau dengan level 45\% (P3) sebaran mikroba lebih sedikit dibandingkan perlakuan lainnya sedangkan cemaran bakteri paling tinggi terdapat pada kontrol dan P2 (30\%) yaitu sebesar 2,07 log cfu/g, hal ini kemungkinan disebabkan karena penambahan tepung kacang hijau pada level $45 \%$ dapat memberikan struktur sosis dengan kandungan air yang tidak terlalu tinggi, tetapi dapat memberikan kandungan protein yang relatif lebih tinggi. Utafiyani et al. (2018) menyatakan bahwa faktor-faktor yang dapat mempengaruhi pertumbuhan mikroba, diantaranya ketersediaan nutrisi, $\mathrm{pH}$, kadar air 
produk, ketersediaan oksigen dan potensi oksidasi reduksi.

Menurut Fakolade dan Omojola (2008) produk sosis akan mengandung toxic dan berbahaya bila pencemaran koloni mikroba mencapai angka lebih dari 1 x $10^{5} \mathrm{cfu} / \mathrm{g} \quad(5 \mathrm{log}$ cfu/g) dan berdasarkan SNI (1995) maksimal cemaran bakteri pada produk sosis sebesar $1 \mathrm{x}$ $10^{3} \mathrm{cfu} / \mathrm{g}$ (3 $\log \mathrm{cfu} / \mathrm{g}$ ). Hasil penelitian ini menunjukkan bahwa pembuatan sosis daging kelinci dengan penambahan tepung kacang hijau sampai level $45 \%$ masih aman untuk dikonsumsi karena hasil uji cemaran bakterinya tidak melebihi standar cemaran bakteri berdasarkan standar SNI yaitu $3 \log \mathrm{cfu} / \mathrm{g}$.

\section{Kesimpulan}

Substitusi tepung kacang hijau pada pembuatan sosis daging kelinci pada level 15\% memberikan warna, rasa, tekstur dan aroma yang terbaik yaitu warna dengan skor 5,28 tergolong warna terang; rasa dengan skor 5,95 tergolong enak, terstur dengan skor 5,99 tergolong lembut dan aroma dengan skor 5,31 tergolong sedap. Substitusi tepung kacang hijau dalam pembuatan sosis daging kelinci baik pada level 15\%, 35\% dan $45 \%$ dapat menekan pertumbuhan koloni bakteri dengan kisaran nilai sebesar 1,75-2,07 log cfu/g yaitu dibawah standar cemaran bakteri yang ditetapkan oleh SNI yaitu sebesar $3 \log$ $\mathrm{cfu} / \mathrm{g}$.

\section{Ucapan terima kasih}

Ucapan terima kasih disampaikan kepada segenap tenaga Laboran Laboratorium Pengolahan Hasil Peternakan dan Laboratorium Mikrobiologi Fakultas Peternakan Universitas Mataram yang telah membantu dalam proses penelitian.

\section{Referensi}

Badan Standar Nasional (1995). Sosis Daging (SNI 01-3820-1995). Jakarta (ID): Badan Standar Nasional.

Barus., J. G, Santosa. P. E, \& Septinova. D. (2017). Pengaruh lama Perendaman dengan Menggunakan Larutan Daun Salam (Szygium Polyanthum) Sebagai Pengawet Terhadap Total Plate Count Dan Salmonella Daging Broiler. Jurnal
Riset dan Inovasi Peternakan e-ISSN: 2598-3060. 1(3):42-47.

Bulkaini, Samiadi, D. Kisworo \& Hakim (2014). Produksi Pangan Fungsional Berbasis Daging Sapi Dengan Tambahan Bahan Nabati Tepung Kacang Hijau Untuk Meningkatkan Kualitas Sosis. Laporan Penelitian Fakultas Peternakan Universitas Mataram.

Bulkaini, Djoko Kisworo \& M. Yasin (2019). Karakteristik Fisik dan Nilai Organoleptik Sosis Daging Kuda Berdasarkan Level Subtitusi Tepung Tapioka, Jurnal Veteriner, 20 (4): 548557.

Fakolade, P.O \& A. B. Omojola (2008). Proximate Composition, $\mathrm{pH}$ Value, and Microbiological Evaluation of Kundi (Dry Meat) Product from Beef and Camel Meat. Nigeria: University Of Ibadan.

Genisa, J., N. K. Sukendar, J. Langkong \& N. Abdullah (2015). Analog Bakso Sehat dari Protein Kacang Merah (Phaseolus vulgaris $L$ ). Jurnal AgriTechno. 8(1): 1-9.

Irianti, D. (2019). Pengaruh Level Substitusi Tepung Tapioka Terhadap Nilai Organoleptik Dan Jumlah Bakteri Sosis Daging Kuda. Skripsi . Fakultas Peternakan. Universitas Mataram.

Kusumastuti, K \& A Fitriyono (2013). Pengaruh Penambahan Bekatul Beras Merah Terhadap Kandungan Gizi, Aktivitas Antioksidan dan Kesukaan Sosis Tempe. Journal of Nutrition College, 2 (1): 29.

Lestari, Ema, Kiptiah \& M. Apifah (2017). Karakteristik Teoung Kacang Hijau dan Optimasi Penambahan Tepung Kacang Hijau sebagai Pengganti Tepung Terigu dalam Pembuatan Kue Bingka. ISSN 2407-4624.

Meilgaard, M., Civille G.V., \& Carr B.T. (2000). Sensory Evaluation Techniques. Boca Raton, Florida: CRC Press.

Prasetyo, Ichsan \& Bulkaini (2015). Produksi Pangan Fungsional Berbasis Daging Ayam Dengan Tambahan Bahan Nabati 
Tepung Tapioka Untuk Meningkatkan Kualitas Sosis. Laporan Penelitian Fakultas Peternakan Universitas Mataram.

Purwosari A.G. \& Choirul Anna Nur Afifah (2016). Pengaruh Penggunaan Jenis Dan Jumlah Bahan Pengisi Terhadap Hasil Jadi Sosis Ikan Gabus (Channa Striata). E-journal Boga, 5 (1): $211-228$

Rukmana, H. R. (2014). Wirausaha Kelinci Potong Secara Intensif. Yogyakarta. Lily Publisher.

Setyaningsih, Dwi., Apriyantono, A. \& Sari. M. P. (2010). Analisis Sensori untuk Industri Pangan dan Agro. IP ress Bogor.

Soekarto ST. (1981). Penilaian Organoleptik. Bogor: Pusbangtepa, Institut Pertanian Bogor.

Soeparno (2005). Ilmu dan Teknologi Daging. Yogyakarta. Gadjah Mada University Press.

Soeparno (2009). Ilmu dan Teknologi Daging. Cetakan V. Gadjah Mada University Perss. Yogyakarta
Standar Nasional Indonesia (2000). SNI 010366-2000 tentang pengujian total mikroba.Dewan Standarisasi Nasional. Jakarta.

Steel, R.G.D \& J.H. Torrie (2015). Prinsip Dan Prosedur Statistika. Penterjemah Bambang Sumantri. Gramedia Pustaka, Jakarta.

Utafiyani, Ni Luh Ari Yusasrini, \& I G.A Ekawati (2018). Pengaruh Perbandingan Tepung Kacang Hijau (Vigna Radiata) Dan Terigu Terhadap Karakteristik Bakso Analog. Jurnal ITEPA, 7 (1): 12-19.

Winarno, F. G. (2004). Kimia Pangan dan Gizi. Gramedia Pustama Utama. Jakarta.

Yunisuryani (2013). Tepung Legum (Kacang Hijau dan Kacang Kedelai). https://yunisuryani2013.wordpress.com/ 2015/07/22/tepung-legum-kacang-hijaudan-kacang-kedelai/. Diakses pada tanggal 24 September 2020. 